\title{
The Interpretation of Biogeochemical Growths on Gold Coins from the SS Central America Shipwreck: Applications for Biogeochemistry and Geoarchaeology
}

\author{
Erik B. Melchiorre ${ }^{1,2, *\left(\mathbb{D}, \text { Bryan H. Seymour }^{2} \text { and Robert D. Evans }\right.}{ }^{3}$ \\ 1 Department of Environmental Sciences, University of California, Riverside, 900 University Avenue, \\ Riverside, CA 92521, USA \\ 2 California State University, San Bernardino, Department of Geological Sciences 5500 University Parkway, \\ San Bernardino, CA 92407, USA \\ 3 American Numismatic Association, Colorado Springs, CO 80903, USA \\ * Correspondence: emelch@csusb.edu; Tel.: +01-909-537-7754
}

Received: 29 May 2019; Accepted: 27 June 2019; Published: 5 July 2019

\begin{abstract}
Black crusts that formed on gold coins recovered from the 1857 shipwreck of the SS Central America played a key role in their preservation in a near original state. Within a few years of the sinking, the significant quantities of iron and steel on the shipwreck produced laminar geochemical precipitates of fine-grained iron minerals on the coins. This coating served to armor the coins from future chemical or biological attacks. Once coated, the coins were colonized by at least two distinct populations of gold-tolerant bacteria that precipitated abundant nanoparticulate gold in the black crust material and produced biomineralized bacteria in a web-like mat. Above this middle layer of black crust, the outer layer consisted of a geochemical reaction front of euhedral crystals of iron sulfate and iron oxy-hydroxide species, formed by the interaction of seawater with the chemical wastes of the bacterial mat. Understanding this process has application for assessing the diverse and extreme conditions under which nano-particulate gold may form through biological processes, as well as understanding the conditions that contribute to the preservation or degradation of marine archaeological materials.
\end{abstract}

Keywords: gold; nanoparticulate; C. metallidurans; SS Central America; biomineralization

\section{Introduction}

\subsection{Significance of the California Gold Rush}

The decade following the discovery of gold in California was arguably one of the most catalytic times in US history. The California Gold Rush greatly accelerated western migration by Europeans, and eastern migration by Asians and Pacific Islanders. Furthermore, it significantly strengthened the economy of the young United States of America, and stripped native peoples of their ancestral lands, killing up to $80 \%$ of their population [1-3]. In just two short years, California went from a remote and sparsely populated outpost of Mexico to US statehood. James Marshall is credited with the official discovery of gold in California on January 24, 1848 at the site of a sawmill he was building for John Sutter on the American River [4], though gold was known to occur in California far earlier [5,6]. Yet, little remains of the original geological materials, coins, and other artifacts from the first decade of this crucial period of American history. For example, period coins can provide insights on commerce patterns through wear patterns if verifiably preserved from the early days of the gold rush. Hoards or 
caches of period coins may also reveal the existence or prevalence of contemporary counterfeiting. Similarly, preserved placer gold samples can provide insights on which areas were mined, when they were mined, and even what techniques were used. However, the vast majority of placer gold and gold coins from this period have not survived the melting pot, having long ago been converted into new articles. Furthermore, surviving specimens have limited geochemical or archeological context, having often been subjected to aggressive cleaning, subsequent wear, or both. There is also the issue of being certain of an item's provenance or historical authenticity. The scarcity of such direct archeological and geological evidence from the gold rush period of California was significantly lessened with the discovery of the SS Central America shipwreck site, providing scientists with a trove of material as a well-preserved time-capsule from 1857.

\subsection{The Loss of the SS Central America}

The SS Central America was a steam-powered side-wheel ship, $85 \mathrm{~m}$ (278 feet) long and $12 \mathrm{~m}$ (40 feet) wide [7]. The voyage for the passengers and materials of the SS Central America began when the SS Sonora commenced the two-week west coast leg of the journey, departing from San Francisco on 20 August, 1857 and bound for Panama (Figure 1). From Panama, the passengers and cargo from the SS Sonora, and several smaller ships, crossed the isthmus by railroad and re-embarked on the SS Central America on September 8, 1857 for a nine-day journey to New York [4]. Aboard the ship was a broadly reported commercial shipment of $\$ 1,219,189.43$ in gold. Pure gold at the time carried a value of $\$ 20.672$ per troy ounce $(31.1035 \mathrm{~g})$. Approximately $87 \%$ of the gold's face value in the commercial shipment consisted of assayers' ingots, essentially the raw placer gold or other gold (like foreign coins) melted and poured into bar form with the precise weight and purity determined during the process. These gold bricks, as well as the placer gold found on the site, consisted on average of $\sim 88 \%$ gold with the remainder mostly silver. The US federal gold coins, that mostly comprise the other $13 \%$ of the commercial shipment, are made of an alloy of $90 \%$ gold and $10 \%$ copper, sometimes with small amounts of silver substituting for copper in the mix. Some contemporary accounts estimate that the passengers may have carried a cumulative amount equal to this 2,000-plus kilogram commercial shipment. The first three days at sea, the SS Central America battled rough weather, but with a seasoned captain and crew, and a large, powerful steam engine to instill confidence, the conditions were not deemed hazardous enough to return to port. What captain William Lewis Herndon and his crew had no way of knowing, was that they were sailing on an intercept course with a category two hurricane [8]. On 11 September, 1857, under worsening seas, a leak at one of the side-wheel paddle gaskets began filling the engine room with sea water, shutting down the steam engines and bilge pumps, and sealing the fate of the ship [7]. All the female passengers and all but one of the children were rescued by small ships in the area, while the men fought to save the sinking ship and its fortune of gold. The ship sank the next day at 8:00 pm, claiming the lives of 425 passengers and crew, and a reasonably approximated 4000 kilograms of gold. The news of the loss of the significant, documented, commercial gold shipment (modern gold value of approximately US $\$ 75$ million) plus an unknown amount of passenger wealth deepened the Financial Panic of 1857, which crippled the nation up through the start of the American civil war [9].

\subsection{Discovery of the Shipwreck, and Recovery Efforts}

In 1983, Tommy Thompson, an ocean engineer, conceived a project to search for the shipwreck site of the SS Central America scientifically. Utilizing historical information in a complex mathematical model using Bayesian search theory and the critical path method, his company generated a search probability map to aid in finding the sunken ship. Historical data used in the model included wind speeds during the storm, the condition of the vessel, known locations from the ship and rescue ships, and accounts of the sinking provided by the survivors [7]. Review of sonar records within the search areas revealed an anomaly that the experts initially deemed a "large geological feature." 


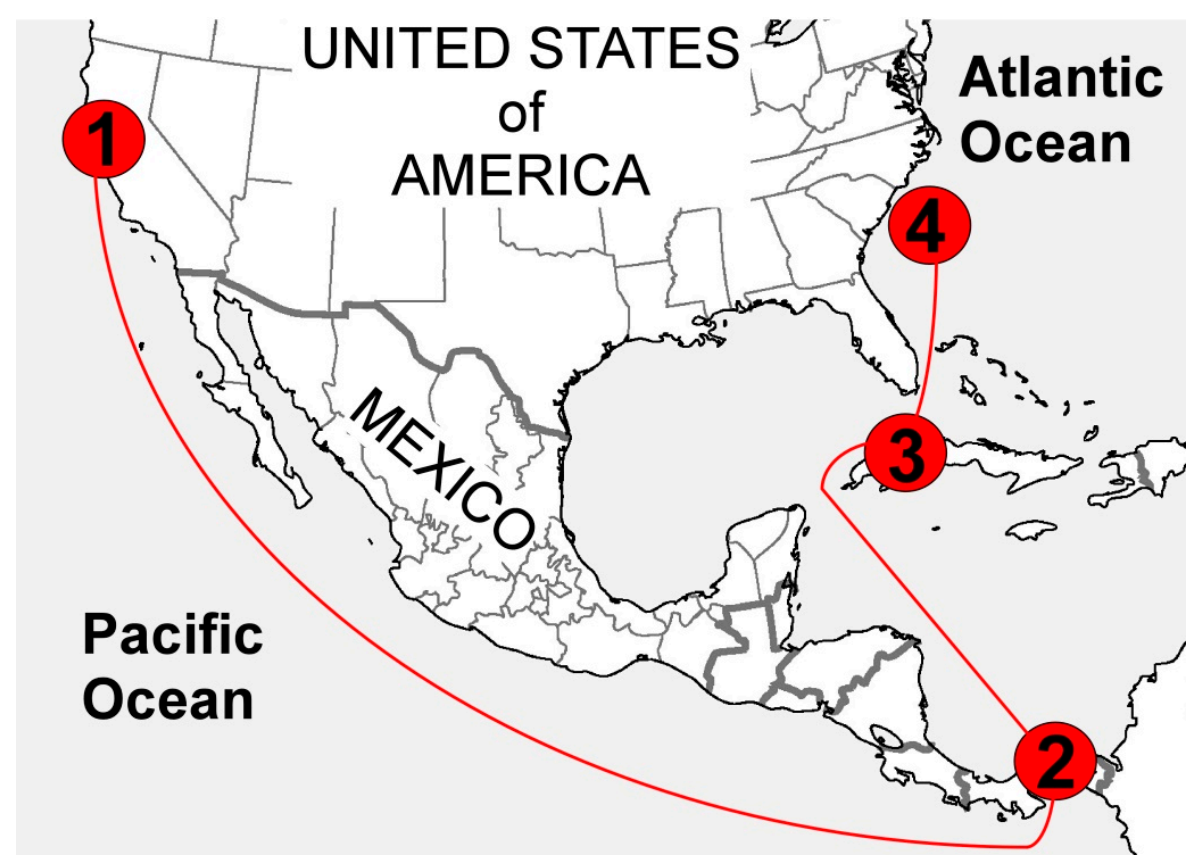

Figure 1. Map of the route of the SS Sonora from San Francisco (1), to Panama (2), where passengers embarked on the SS Central America for Cuba (3) with an ultimate destination of New York. The ship sank in the Atlantic Ocean on September 12, 1857 during a hurricane off the coast of the Carolinas (4).

Located 150 nautical miles $(280 \mathrm{~km})$ off the Carolina coast on a transitional feature of the continental slope, known as the Blake Ridge, this site was first explored using the NEMO-ROV submersible on the anniversary week of the sinking, on 11 September, 1988. Upon reaching the seafloor, there was no doubt that this was the shipwreck of the SS Central America. The large mid-ship paddle wheel and other distinctive features were the first signs. However, confirmation was provided when they observed that the seafloor was littered with gold, in an area that became known as the "garden of gold" (Figure 2). The excavation that followed took four summer seasons to recover over 1,900 $\mathrm{kg}$ (two tons) of the lost gold.

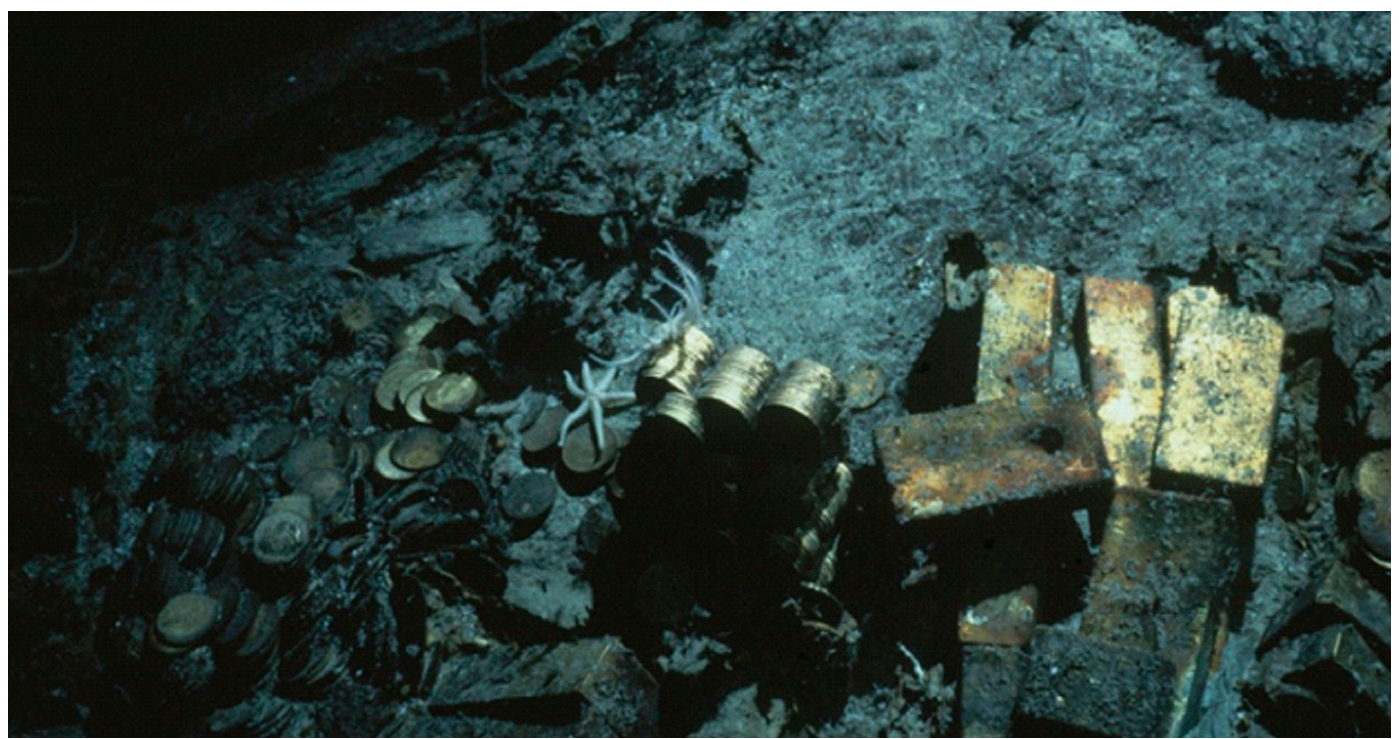

Figure 2. Seafloor image of gold from the shipwreck of the SS Central America. Note the formation of black crusts on the coins and some of the gold bars. These crusts appear black to grey in the image, due to constraints of seafloor lighting. Image courtesy of California Gold Marketing Group. 
In April of 2014, a second recovery team went to sea for five months, retrieving an additional 3100 gold coins including hundreds recovered from within an iron safe. Furthermore, inside the safe were bags, vests, and saddle bags containing placer gold dust and gold-quartz specimens. Just as with the earlier recovery, the surfaces of these gold coins (but rarely the placer gold) were coated with black crusts. These crusts on the artifacts are painstakingly removed with mild solutions that do not disturb or react with the underlying gold (Figure 3). However, the questions remain: what are these black crusts, and why do they form on a non-reactive noble metal?

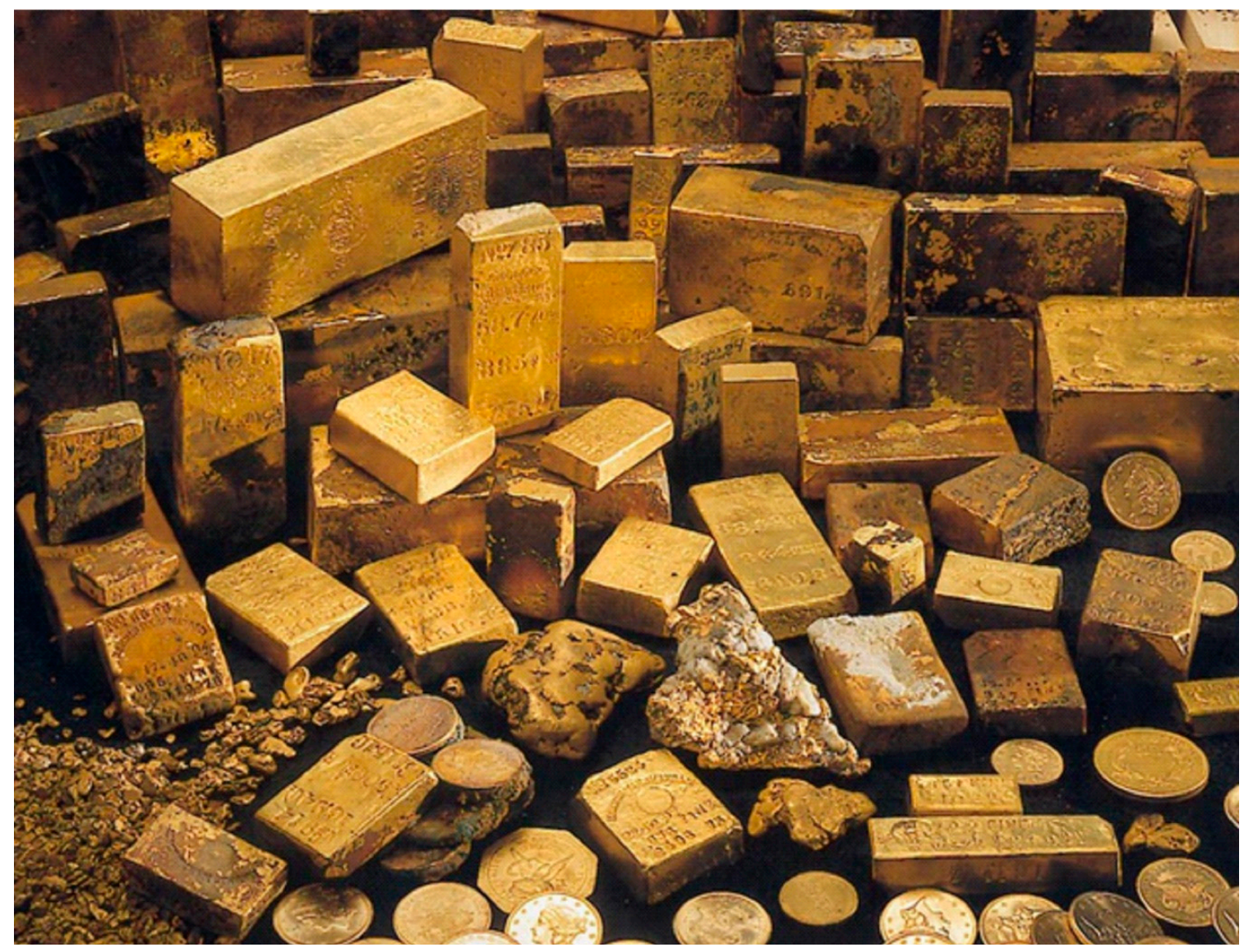

Figure 3. Image of some of the gold recovered from the shipwreck of the SS Central America after curatorial treatment. The black crusts have been retained on some assay bars (upper right and left) for esthetic purposes. Image courtesy of California Gold Marketing Group.

\subsection{Previous Work}

The S.S. Central America shipwreck site offers a myriad of opportunities for scientific and historical studies. Scientific publications on aspects of the shipwreck began with a 200-plus page monograph [7], which was followed by many articles, theses, and dissertations, including works on the biology of the site (many species new to science), as well as material science and costume history related to clothing (textiles), and other artifacts found in passenger trunks. No previous scientific studies have focused specifically on the mineral crusts found growing on the SS Central America gold. However, significant studies have been done on black crusts growing on natural placer gold [10,11]. These black crusts on placer gold are associated with the secondary formation of natural placer gold particles with iron oxyhydroxide coatings (young biogenic gold) and are derived from anoxic wet environments, which favor microbial growth within the microscopic cracks of placer gold [12-14]. In addition, deep-sea corrosion studies [15] provide valuable information on sources of reactants for the formation of secondary crusts such as those found on the gold from the SS Central America. 


\section{Materials and Methods}

Five samples of black crusts were obtained from the surface of $\$ 20$ (one troy ounce) gold coins that were recovered from the SS Central America shipwreck site. Each sample weighed $\sim 0.1$ gram and consisted of small flakes of material up to $1 \mathrm{~cm}$ on the longest axis. Removal of these crusts was facilitated by soaking in a sodium salt solution. This exact methodology and chemistry is proprietary, and was performed by Robert Evans at laboratory facilities in southern California. These samples were provided courtesy of California Gold Marketing Group, the owner of the treasure.

Black crust samples were structurally and chemically characterized, using methods described by [10], to determine possible biogenicity. Samples were placed on their flattest side to expose the maximum surface area and photographed under a binocular microscope. A Phenom XL Scanning Electron Microscope (SEM) was used to capture Secondary Electron (SE) and Backscatter Electron (BSE) images using an acceleration voltage of $15 \mathrm{kV}$. Samples were not carbon coated, but were grounded using carbon tape. Porous zones and zones of variation in surface texture were targeted for analysis. The same instrument was used for Energy Dispersive X-ray (EDX) element measurements of major and minor element abundances, using standard off-peak interference and matrix corrections [16,17], in addition to calibrations using registered standards provided by the manufacturer. The error associated with the in-situ trace element analyses is less than $\pm 2 \%$.

\section{Results}

The $\$ 20$ gold coins from which the black crusts were recovered are dated 1857, with a San Francisco mint mark. These coins are Liberty Head double eagles, a design by James Longacre, which was in production between 1850 and 1907 [18]. These coins are in uncirculated condition and presumed to be part of the large shipment of these coins that was being transported by businesses to the east coast of the country. A representative sample of one of these coins, superimposed with an image of a fragment of black crust is provided in Figure 4 to show relative positioning.
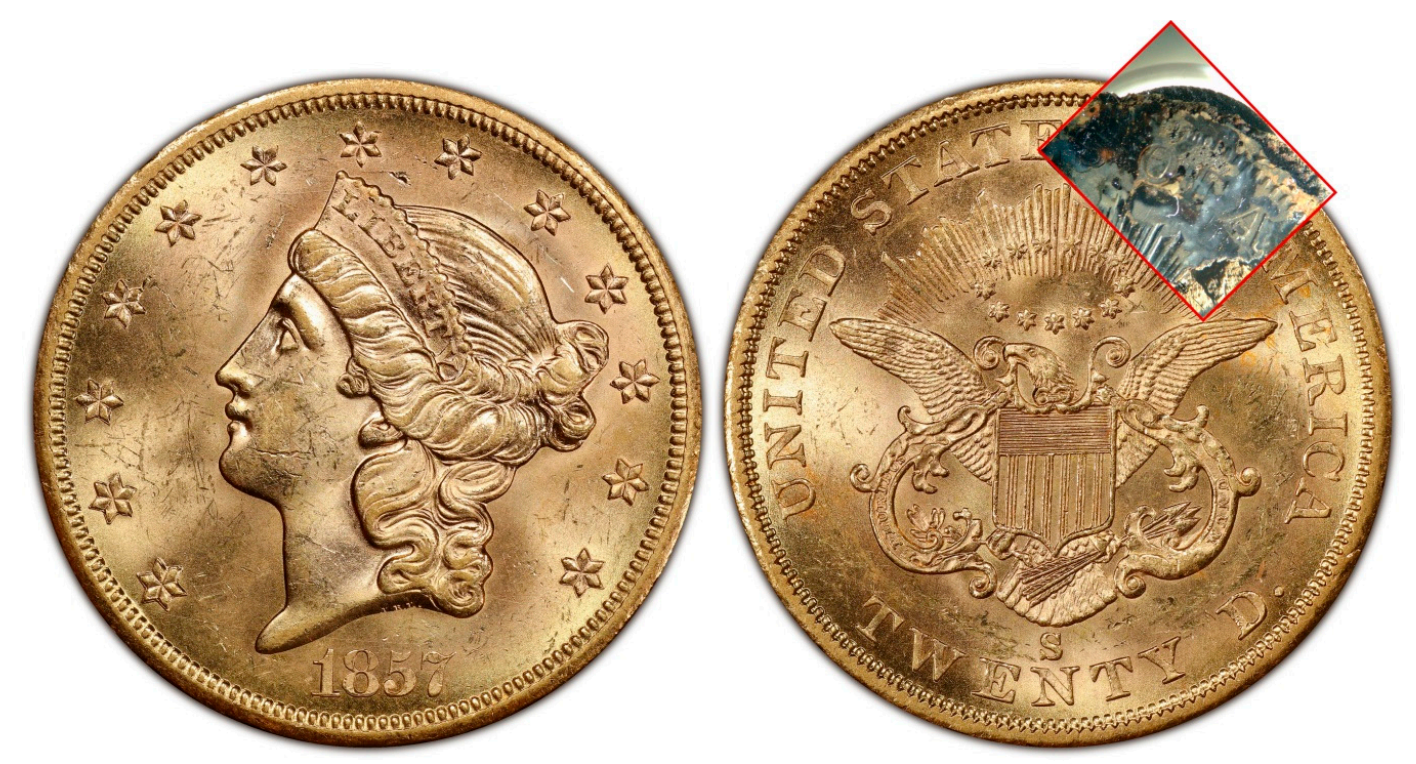

Figure 4. Image of an 1857-San Francisco mint $\$ 20$ gold coin from the shipwreck, showing the preserved cast of the coin on a fragment of black crust (red box). The image of the crust has been inverted to align with the coin, as it is a negative-relief cast. The yellow areas on the crust are not gold, but hydrated iron oxides. Coin image courtesy of Professional Coin Grading Service.

The black crusts are $<1 \mathrm{~mm}$ thick and fragile. The outer surfaces have a porous dull black to dark-red color. The surfaces that were in contact with the coin form a negative-relief cast that faithfully reproduces details of the coin (Figure 4), and are vitreous, laminated, and smooth. 
The morphology of all black crust samples examined under the binocular and SEM microscopes were found to consist of an identical three layers (Figure 5A). The lower-most layer, deposited directly on the surface of the coin, exposes a smooth uniform surface (Figure 5B). The middle layer has "spongy" texture of elongate mineralized structures and cell-like forms with abundant nano-particulate gold (Figure 5C). The upper-most layer consists of blocky well-formed euhedral crystals up to 25 microns in length (Figure 5D).

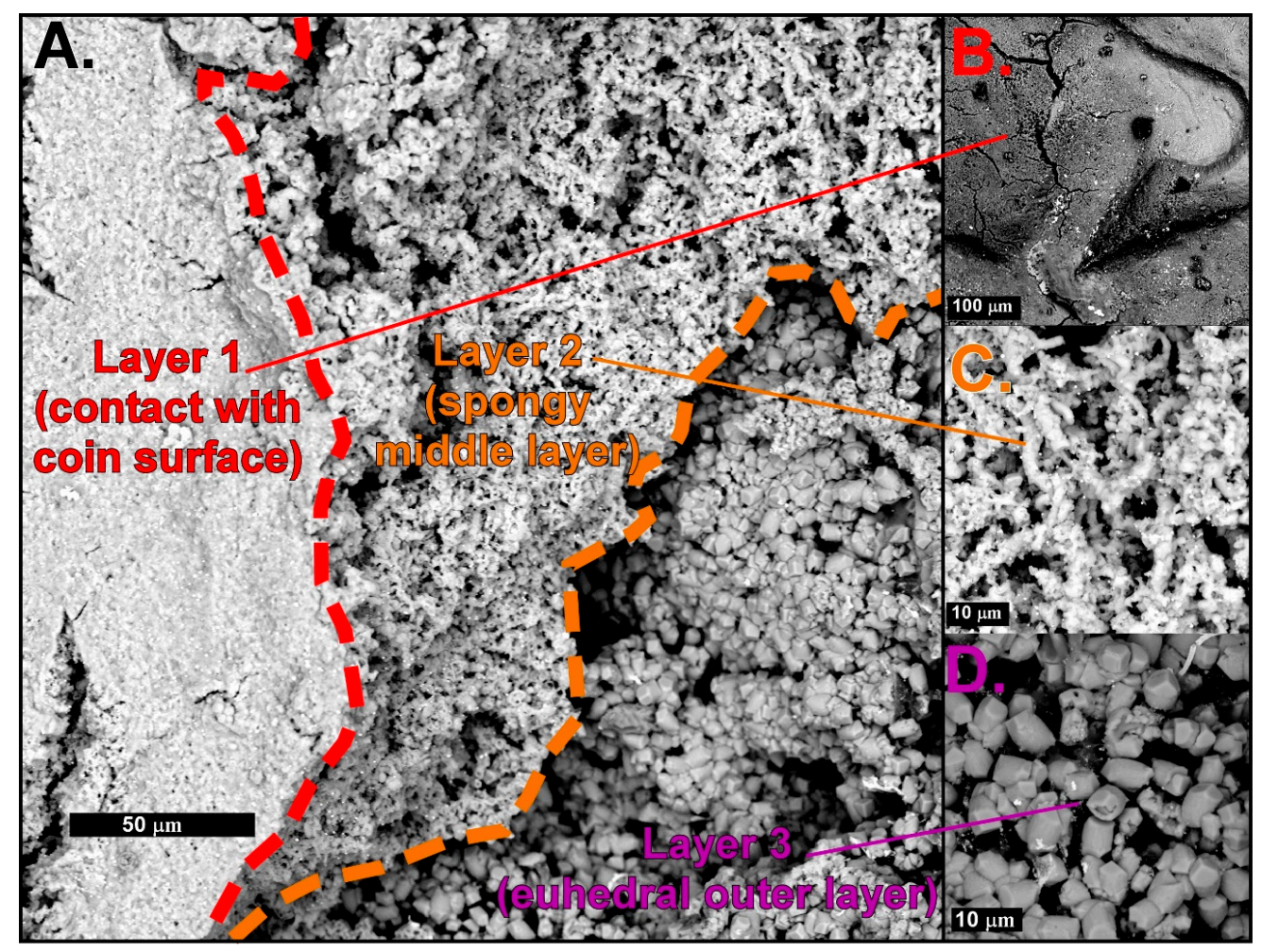

Figure 5. SEM images of the three distinct layers within black crusts at 1,100×: coin surface, biomat layer, and outer layer. (A) Exposed section of the three layers along a natural fracture, (B) layer 1 with letter imprint from coin surface (630×) and crypto-crystalline iron oxides (grey), (C) middle layer 2 with spongy growths of iron oxides (grey), and (D) surface layer 3 with euhedral iron sulfate minerals (dark grey) (C and D; both 5,900×).

The lowermost black crusts consist of smooth weakly laminated layers of iron sulfate and less commonly iron oxide minerals, as determined by EDX. It was not possible to determine the exact speciation of these minerals by X-ray diffraction due to the small quantity of samples and access to instrumentation. Desiccation cracks are common on this layer. Crystals $>0.1$ micron are rarely observed in association with this layer. This layer faithfully reproduces a negative cast of the coin substrate to which it was attached, with preservation of details down to the micron scale.

The middle crust consists of iron oxide (hydroxide) minerals, siderite $(<2 \% \mathrm{Ca})$, calcium sulfate (hydroxide) minerals, organic debris from the shipwreck, base metal sulfides (e.g., pyrite, chalcopyrite, and galena), and abundant nano-particulate gold. Attached to the elongate pseudo-crystals of the iron oxide/iron sulfate minerals are abundant nano-particulate gold grains, typically one micron or less in size with an alloy chemistry described below. There are many potential hydrated iron oxide mineral species, and 14 known hydrated calcium sulfate mineral species. However, the exact speciation of the iron oxides and iron sulfates is unknown due to instrument access and sample quantities, which were insufficient for proper XRD characterization.

The uppermost crust layer consists of several generations of iron oxides, siderite $(<4 \% \mathrm{Ca})$, iron sulfate minerals, and rarely pyrite, chalcopyrite, and galena. These crusts contain some combination of 
the 19 known hydrated iron oxide species and 36 known hydrated iron sulfate species. However, as mentioned above, the determination of exact speciation was beyond the scope possible with the existing study and instrumentation. Furthermore, the exact mineralogy of the original hydrated crusts on the deep seafloor has probably been altered to some degree by the recovery and drying of the samples. If this has indeed occurred, it is likely that the well-defined crystal forms in this layer are pseudomorphs that preserve the form of the original seafloor species. This in turn complicates the potential for existing mineral identification based on crystal structure. Future expeditions to the shipwreck site may produce fresh material that can be properly preserved in cold seawater, in quantities that will permit a detailed mineralogical study of these crusts.

Some elements such as elemental sulfur and some metals such as molybdenum are found irregularly distributed through only the middle crust layer, and in close association with potential biogenic forms that are similar in size and shape to cell structures (Figure 6A,B). Other features such as microfossils (5-100 microns) and organic debris from the shipwreck were found embedded in the outermost two layers of the black crusts (Figure 6C,D). Sodium carbonate and sodium sulfate crystals form overgrowths on some outer portions of the crusts (Figure 6E). Quartz sand grains with conchoidal fractures are also found within the crusts (Figure 6F).

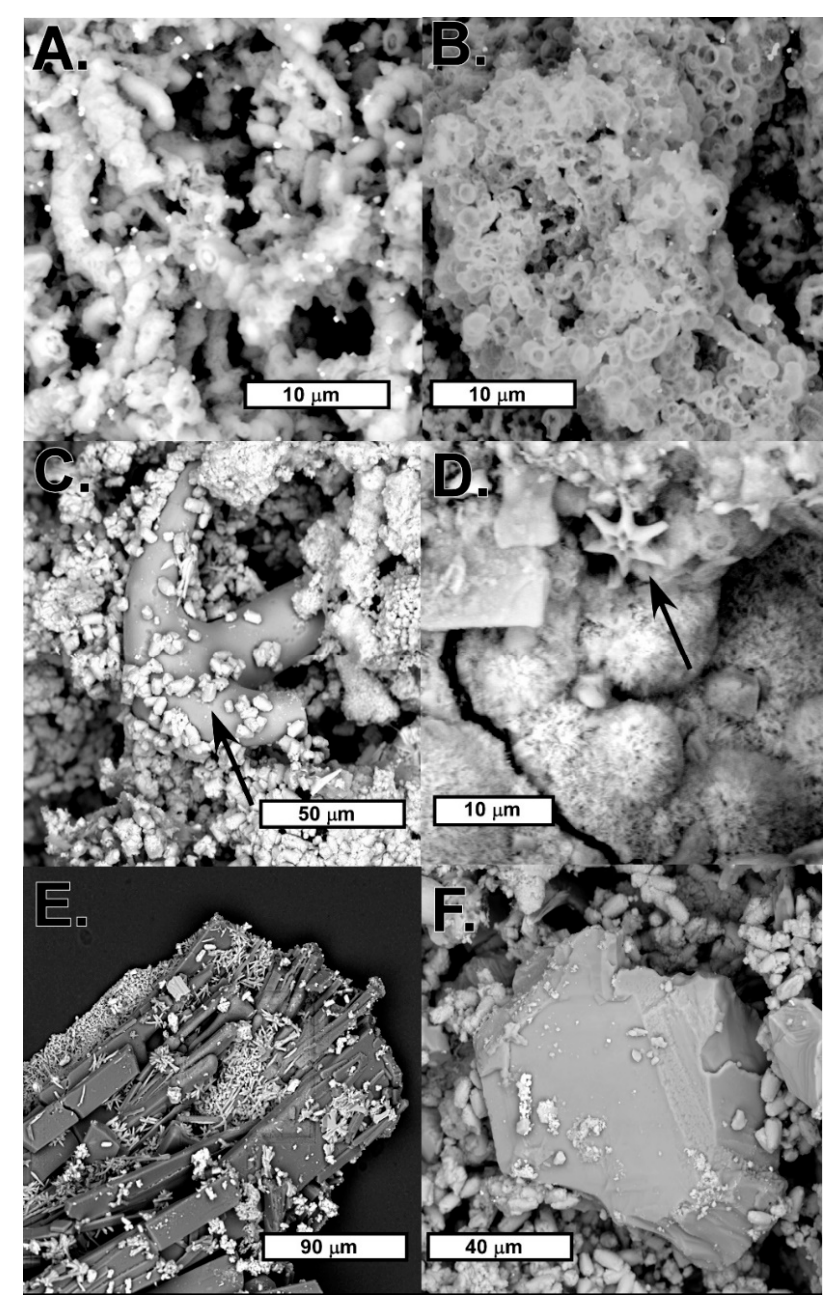

Figure 6. SEM images of features from black crusts. (A,B) Cell-like forms from the middle crust, (C,D) remains of microscopic marine life embedded within black crusts (highlighted by arrows), (E) calcium sulfate crystals (grey) with sodium carbonate overgrowths (white), and (F) a conchoidally fractured sand grain (center of image). 
Nanoparticulate gold is present throughout the uppermost two layers, but is particularly abundant in the middle layer. These gold grains vary in size from 0.2 to 12 microns in length along the longest axis and show a wide range of alloy chemistry (Figure 7). Nanoparticulate gold grains ranged from 85.5 to $2.1 \mathrm{wt}$.\% gold, with an average of $58.9 \mathrm{wt} . \%$ gold. Silver ranged from 28.5 to $<0.01 \mathrm{wt} . \%$, with an average of $17.1 \mathrm{wt} . \%$, but was not present in all samples. Copper in the gold alloy ranged from 10.9 to $<0.01 \mathrm{wt} . \%$, with an average of $4.7 \mathrm{wt} . \%$, but similarly was not present in measurable quantities in all samples. Iron was present in significant quantities in all but one sample of nanoparticulate gold, and ranged from 93.6 to $7.5 \mathrm{wt} . \%$, with an average of $25.9 \mathrm{wt} . \%$. Sulfur, when present, ranged from 21.0 to $4.3 \mathrm{wt} . \%$, with an average of $13.5 \mathrm{wt} . \%$. Loose material from a crust with high iron nanoparticuate gold was sonicated and re-analyzed to reveal an iron content below detection limits of $0.01 \mathrm{wt} . \%$.

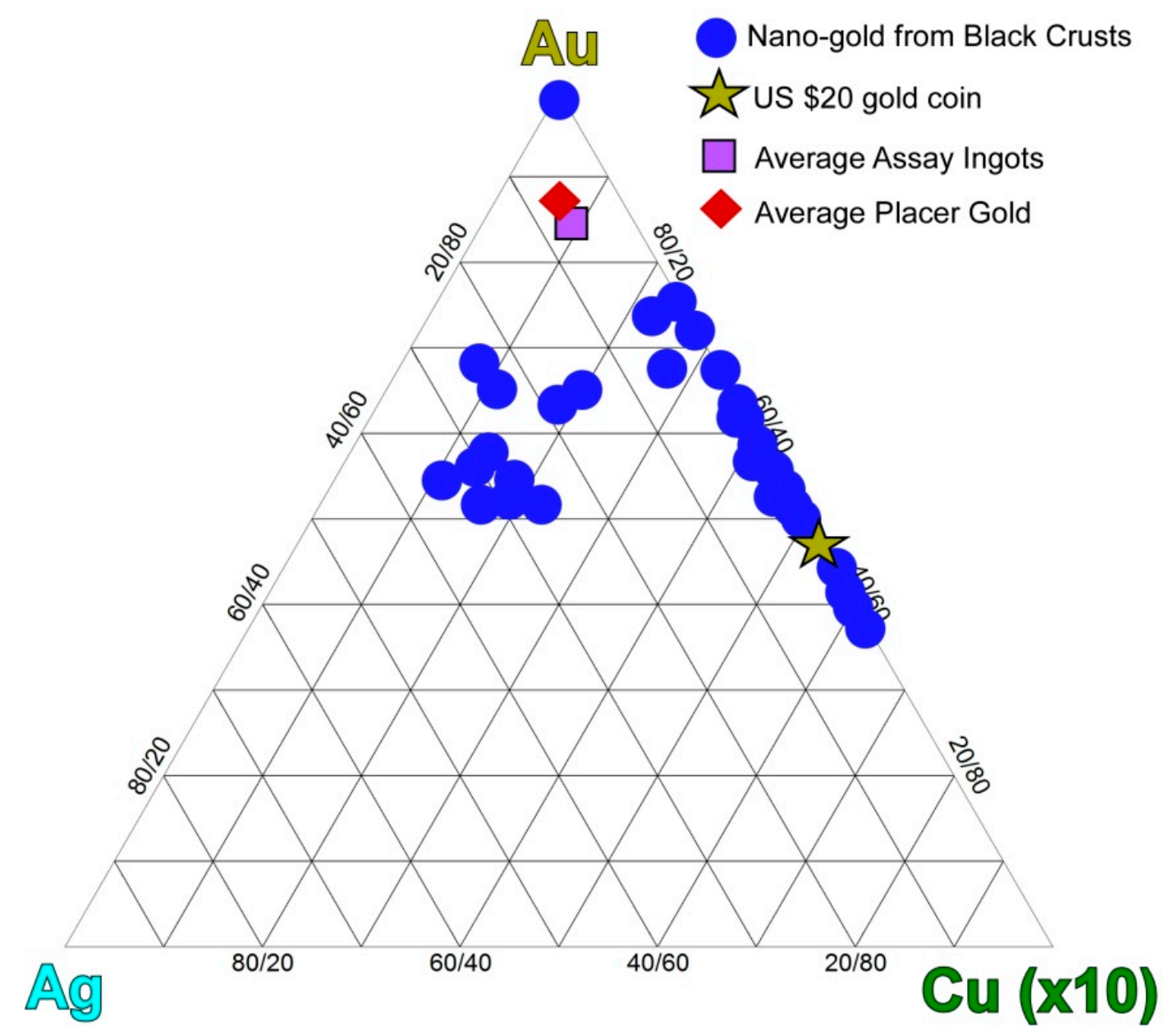

Figure 7. Ternary plot of fifty-six chemical analyses of nanoparticulate gold alloys from black crusts (blue dots). Note the exaggeration of the $\mathrm{Cu}$ axis used to magnify variations of this element relative to the other two. The composition of an 1857-S US \$20 gold coin (yellow star), average placer gold (red diamond), and assay ingots (purple square) from the SS Central America are shown for reference.

\section{Discussion}

\subsection{Mineral Crust Formation}

The smooth and finely laminated black crust layer that was in direct contact with the coins contains well-preserved casts of letters and other details from the coins (Figures 4 and 5B), in addition to very fine-grained mineralization. These data suggest that this layer was deposited by relatively rapid precipitation from a supersaturated source that provided many fine-grained nucleation points. The Fe-dominated chemistry of this layer likely reflects the initial dissolution of the 750 tons of ironwork 
found within the ship, and its re-precipitation as stable minerals through reactions with seawater. Desiccation cracks in this layer are probably the result of drying following recovery of the coins and their attached black crusts from the shipwreck.

The middle "biomat" layer contains significant amounts of nano-particulate gold alongside mineralized cell-like material, biological debris, and other mineral growths. The diverse mineral species occurring as micron-scale euhedral crystals within the middle crust (e.g., galena, pyrite, and chalcopyrite) indicate that the coins' environment changed significantly as the shipwreck continued to degrade and react with seawater. The significance of this layer of black crust is described in detail in Section 4.2.

The outer layer consists of a network of euhedral crystal intergrowths of iron oxide and iron sulfate minerals with rare isolated nano-particulate gold grains. The dominance of iron minerals as larger well-formed crystals is most likely due to their formation at a time when corrosion of the shipwreck iron had reached a lower steady state and provided minimal saturation, and the interaction of these fluids with the metabolic products from the biomat layer beneath it. The low abundance of transition-group sulfide minerals such as galena and chalcopyrite within this outer crust suggests that these elements were locally depleted from the shipwreck, or armored from further corrosion by their own corrosion products at this time. Sodium carbonate and sodium sulfate crystals form overgrowths on some portions of the outer crusts (Figure 6E) and are likely produced by the drying of the sodium salt solutions used to clean the black crusts from the coin surface, and evaporating seawater.

\subsection{Biomats and Nanoparticulate Gold}

Black crusts on placer gold are believed to form due to iron and manganese depositing bacteria [14, 19]. The SS Central America shipwreck, with several hundred tons of cast iron and carbon steel steam plant and ballast, provides an ideal location for similar biogenic deposits to form in relatively anoxic locations in the seafloor environment [20]. There are two components to the middle layer of the black crusts from the gold coins from the SS Central America. The first is the purported biomat layer itself, while the second is the nanoparticulate gold contained within the biomat layer.

\subsubsection{Biomats}

Upon examination, the middle layer of the black crusts is distinctly different from the layers above and below it (Figure 6A,B and Figure 8). In addition to fossils of various microscopic sea life forms (Figure 6C,D), there is abundant evidence of possible bacterial fossils. The mineralized morphologic forms that are present have virtually identical scale and shape to published images of both live bacteria that are known to grow on metal substrates (Figure 8A,D; [21,22]), and biomineralized bacteria (Figure $8 \mathrm{~B}, \mathrm{E}$; $[23,24]$ ).

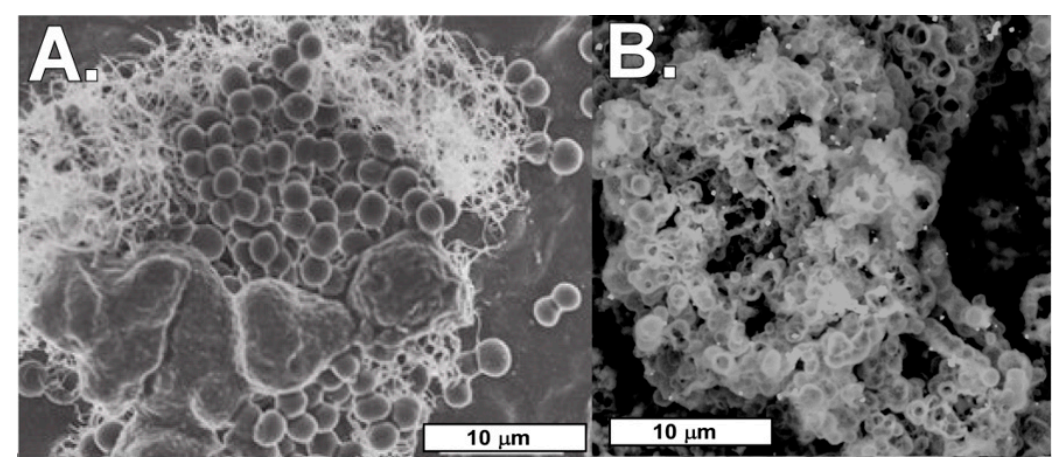

Figure 8. Cont. 


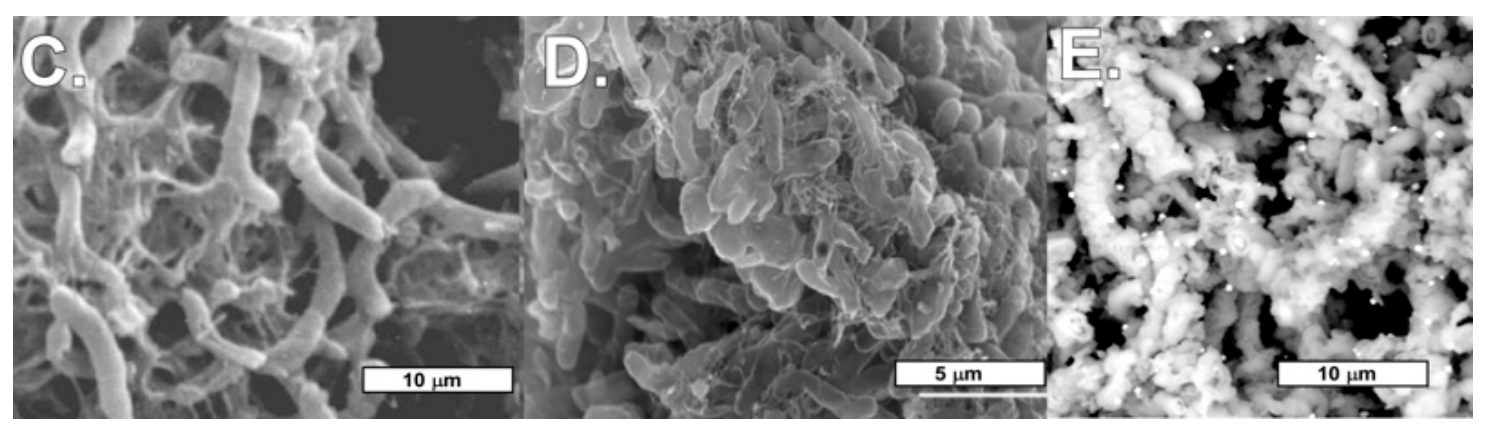

Figure 8. Similarities of known biofilms compared to the biofilms found within the middle layer of the black crusts, as viewed using SEM. (A) Staphylococcus aureus bacteria, part of the firmicutes phylum, easily identified by their ovoid shape and conjoined behavior, averaging two microns in diameter [22]. (B) Image of potential S. aureus bacteria biomat from the middle layer of gold coin black crust from the SS Central America shipwreck. (C) Biofilm (sulphate-reducing) grown under anaerobic conditions on the surface of mild carbon steel [21]. These bacteria are elongate, averaging ten microns in length, and arcuate, creating a dendritic colony form. (D) Heavily biomineralized filamentous bacteria colony (C. metalidurans) growing on the surface of a placer gold nugget [23]. (E) Probable mineralized biofilm from the middle layer of a gold coin black crust from the SS Central America shipwreck. Sub-micron nano-particulate gold (white dots) is present throughout these biofilms.

It should be noted that nonbiological structures like gas bubbles, spherical abiotic mineral growths, and amorphous masses (bacteriomorphs) may have characteristics of coccoid bacteria [25]. However, rod-shaped bacteria are more readily differentiated from abiotic growths [25]. It is likely that the rod/filamentous and ovoid shaped growths from the middle layer of the black crusts from the SS Central America are mineral replacement or permineralization of bacteria. This assertion is based on the standards presented in [25], including morphological characteristics, formation in a favorable environment, and environmental factors which are not favorable for the formation of the most common bacteriomorphs.

There are two putative bacterial morphologies that dominate the middle black crust layer. The first is similar to Staphylococcus aureus bacteria (Figure 8A; [21]), with clusters of conjoined ovoid shapes averaging two microns in diameter. Biomineralized S. aureus bacteria from a modern biofilm grown on stainless steel displays nearly identical characteristics [24]. The individual ovoids of the putative mineralized S. aureus bacteria colonial clusters from the middle layer of gold coin black crusts from the SS Central America have a "deflated" look that is different from the live S. aureus cells. This is likely due to the collapse of these fragile mineralized structures during recovery of the samples from a wet and high-pressure seafloor environment, to a dry laboratory at the surface. Similar post-recovery alteration is echoed by the desiccation cracks, secondary Na-carbonate and Na-sulfate, and probable pseudomorphic crystals seen in other layers of the black crusts. Nano-particulate gold (Figure 8C, sub-micron-sized white specks) is rare but present in these mineralized colonies.

The second, and dominant morphology observed within the black crust middle layer has similar scale and clustering to live Spirilla filamentous biofilms grown on the surface of mild carbon steel [21]. The Spirilla bacteria are elongate, averaging ten microns in length, and arcuate, creating a dendritic colony. Heavily biomineralized and branching filamentous bacteria colonies (including C. metalidurans) similar to these have been observed growing on the surface of placer gold nuggets (Figures 3 and 4 in [23]; Figure 5D in [14]). Micron to sub-micron nano-particulate gold (white dots) is present in significant quantities throughout this biofilm type.

\subsubsection{Nanoparticulate Gold and Probable Gold Sources}

The nanoparticulate gold that occurs in the biomat layer has a range of alloy compositions (Figure 7). Loose material from a crust with high iron nanoparticuate gold was sonicated and 
re-analyzed to reveal a minimal iron content, suggesting that the iron is a weakly-bound surficial coating or dusting. As a result, iron is not included as a major or minor element in this reporting.

Significantly, only one of these analyses is a good match for the composition of the alloy of the gold coins on which they are growing. The 1857-S US $\$ 20$ gold coins on which the black crusts formed is an alloy of $90 \%$ gold, with $10 \%$ copper to add durability and wear resistance [18]. Relative solubilities suggest that copper in the alloy would preferentially corrode significantly faster than the gold as a depletion-gilding effect [26]. Yet, only $9 \%$ of the nanoparticulate gold has a composition consistent with this source, which would be more copper-rich than the presumed coin source. More interestingly, $27 \%$ of the nanoparticulate gold has significant quantities of silver, which is not contained in the alloy of the US $\$ 20$ gold coins beyond traces. The remaining $64 \%$ of the nanoparticulate gold that was analyzed has a composition richer in gold than the coin substrate.

Potential sources of gold, silver, and copper on the SS Central America shipwreck include several tons of US gold and silver coins, unrefined assay ingots, and natural placer gold. It also includes several more tons of copper anti-fouling hull sheathing, and brass fittings.

Silver in the nanoparticulate gold cannot be originating from a gold coin source, as it is not found in the coin alloy beyond the traces permitted by the US Mint policy and federal law. Furthermore, the lack of micro-pitting and preservation of mirror-like finishes (Figure 9) speaks to insignificant corrosion of the coins. It is also unlikely that the silver comes from proximity to US silver coins found on the shipwreck, as silver-rich and silver-poor nanoparticulate gold is often found within a few microns of each other in the same black crust sample. Similarly, proximity to copper sheathing on the hull cannot explain the distribution of copper-rich and copper-poor nanoparticulate gold.

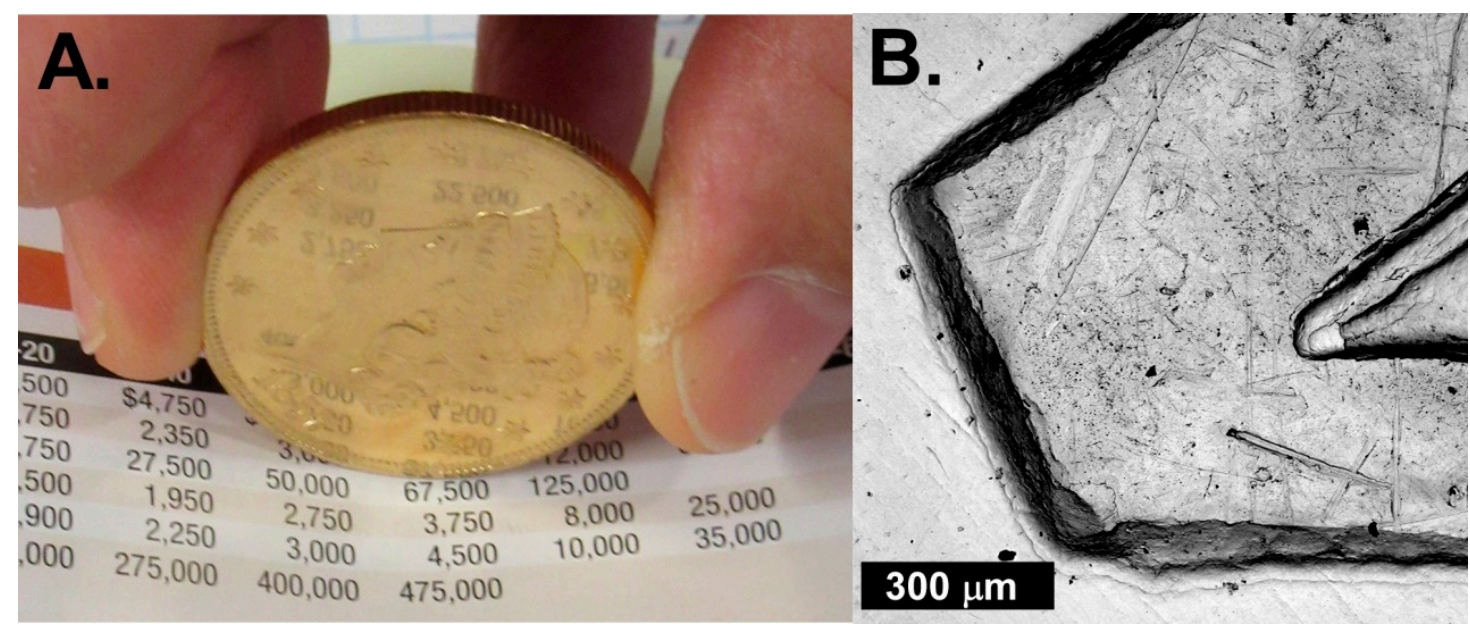

Figure 9. (A) The proof-like finish of an 1857-S US $\$ 20$ gold coin recovered from the shipwreck can still create sharp reflections of text after 157 years on the seafloor. (B) SEM imaging of gold coins from the wreck reveal a sharp mint-like state with no evidence of corrosion or pitting.

However, assay ingots and placer gold from the shipwreck do provide a plausible source for both the copper and silver in the nanoparticulate gold, given the enrichments expected through depletion-gilding release of metals from the source (Figure 7). Assay ingots from the shipwreck average $88 \%$ gold, $11 \%$ silver, and $1 \%$ copper, while the placer gold averages $89 \%$ gold, $10.5 \%$ silver, and $0.5 \%$ copper, based upon EDS analyses and values stamped on ingots recovered from the shipwreck. It is expected that the ingots would be similar in composition to the placer gold, as the ingots are chiefly melted bars of unrefined placer gold. The slightly lower purity of the assay bars likely results from the inclusion of small amounts of transition metal enriched heavy sands included with the placer gold when melted.

The observed range of both silver-rich and copper-rich nanoparticulate gold is possible by the physical process of depletion gilding, but not simultaneously. There are two possibilities that would 
enable this to occur. First, if the conditions of leaching of placer and assay ingot gold were to change significantly, it could produce a significant change in gilding effluent. However, given the buffering capacity of the ocean, such an extreme environmental swing is considered unlikely.

The other mechanism that could produce the range of disparate nanoparticulate gold alloy compositions is biological fractionation. If depletion gilding of placer and assay ingot gold produces a fairly uniform effluent chemistry, it is possible that two populations of metal-tolerant microbes could precipitate different nanoparticulate gold alloys through different metabolic pathways. Cupriavidus metallidurans are known to dominate nanoparticulate gold production in the biofilms on placer gold $[27,28]$. However, a wide range of bacteria is known to be capable of precipitation of gold nanoparticles [29]. It has also been shown that two bacteria capable of gold biomineralization, Cupriavidus metallidurans and Delftia acidovorans, can co-exist within biofilms [30]. The ability of these microbes to detoxify their environment through gold nanoparticle formation has been linked to copper resistance [31], which may be linked to the amounts of copper within the gold alloy. Given that the black crusts have two distinct biomineralization styles, and two distinct nanoparticulate gold alloy populations, it is certainly possible that the range of gold particle chemistry reflects biological fractionation. This biological accumulation of gold is known to occur over the decadal-scale [11], consistent with formation in the black crusts from the shipwreck. The ability of these types of bacteria to compete with sea floor bacterial communities; and their tolerance of cold, saline, high-pressure environments is unknown and should be examined by future workers.

Nanoparticulate gold has been shown to form through reduction by residual organic material such as humic acids and extracellular polymeric substances [11]. Such materials should be abundant around the shipwreck site, due to degradation of abundant wood, cloth, and stored food. Ferric iron may also play a key role as a reducing agent and the precipitation of gold. It is possible that one or both of the nanoparticulate gold populations results from these process. Regardless of the exact combination of mechanisms, it is likely that the range of nanoparticulate gold chemistry reflects two mechanisms, at least one of which is biological.

\subsection{Chronology and Significance of Crust Development}

Creation of black crusts on the gold coins from the shipwreck of the SS Central America began the moment the ship slipped beneath the waves on 12 September, 1857. The large quantity of mild carbon steel and cast iron on the ship was the first material to react, due to its high corrosion potential relative to other metals [32]. Corrosion of these types of metals has been studied at several deep shipwrecks and in the laboratory. Corrosion studies from the RMS Titanic and ships that sank during World War II indicate that significant corrosion may take place during the first couple decades [33-35]. Specifically, studies of the shipwreck of the nuclear submarine Komsomolets suggest corrosion rates up to 75 microns/year [36], while corrosion conditions of the tanker Prestige are believed to be about 57 microns/year [37]. It is known that these corrosion rates change over time, and multiple studies have shown that corrosion peaks within the first couple years to decades, and tail off to a lower steady state in the period that follows [38]. This dissolution of SS Central America's iron, and subsequent reaction with seawater to form a fine-grained precipitate of black to red iron oxides, is expected from evidence at other shipwreck sites [39]. Thus, it seems reasonable that the black crusts initially formed as a fine-grained laminar deposit on the coins, as a chemical process that occurred within the first decade after the sinking.

It is known that the formation of rusticles, or porous icicle-like rust growths on deep-sea shipwrecks, is a biological process $[33,34,40]$. It was in this later stage of shipwreck corrosion that biology began to dominate. These bacteria come from seawater, and are not known to produce nanoparticulate gold. In fact, aqueous gold and silver is highly toxic to most bacteria $[27,28]$. Only specific bacteria, such as Cupriavidus metallidurans and Delftia acidovorans, have developed tolerance to these metals and can exist within biofilms on gold [30]. However, the localized $\mathrm{Fe}^{3+}$ concentrations around the shipwreck at this time would have selected for enrichment of natural iron oxidizing bacteria and may have accelerated 
the rate of iron oxidation. As the shipwreck was slowly colonized by rusticle-producing bacteria, this may have added another source of iron precipitate that could filter onto the coins to add to the laminar layer of the crust. Specifically, rusticles have a lifecycle of colonization, development, and collapse of these fragile structures [34]. Such cycling would produce abundant "rusticle dust," which could further coat the coins when physically remobilized during shipwreck collapse and benthic storms.

At this point, two biological environments were formed. The first is the consortia of bacteria that colonized the iron and steel of the site and contributes to rusticle formation. Members of this consortia could not establish colonies on the gold in the shipwreck, due to precious metal toxicity. Later, the armoring of the gold coins and some assay bars by laminar geochemical precipitates and "rusticle dust" black crusts produced a safer low aqueous gold environment for bacteria to live. This leads to the second consortia of bacteria in the black crusts. Freshly mined natural placer gold was a likely source of gold-tolerant bacteria such as Cupriavidus metallidurans and Delftia acidovorans, which have developed tolerance to gold [30]. It has been shown that these bacteria are capable of survival under less than ideal post-mining conditions for at least 18 months [14]. Assay bars and coins, which have been processed, would have been sterilized of these bacteria. However, following the sinking and reintroduction to an aqueous environment, these natural colonies on the placer gold would thrive and remobilize to precipitate gold as part of their life cycle [30]. In the moderately gold-rich niche-environment of the black crusts, these bacteria would be able to out-compete native ocean-sourced Fe and Mg precipitating bacteria. However, by the time these bacteria could spread to other parts of the site the coins and bars of gold had their armoring of abiological laminar black crusts that protected them from direct attack and precipitation of gold on the coins themselves. A second possibility is that iron oxides played a role in reduction of nanoparticulate gold upon previously existing iron microfossils.

As the biological colonization of the black crusts continues, these bacteria produce waste products from their local environment, including nanoparticulate gold and base metal sulfides. They also produce significant quantities of metabolic wastes such as oxygen, carbon dioxide, and sulfur, which form an "atmosphere" of enrichment around the colonies. These elements react with the dissolved iron from the ship to produce iron oxides, iron carbonate, and iron sulfates. These form larger (up to 25 micron) euhedral crystals because of the low saturation and long period of reaction (Figure 5D).

These black crusts appear to have played a key role in the exquisite state of preservation of the gold coins (Figure 9). Gold-precipitation bacteria are clearly present in the materials of the shipwreck site. In natural environments, as little as 7.6 years are required to produce cycles of gold dissolution and re-precipitation, which can produce spectacular structures both into and onto the gold substrate [11]. Similarly, a 1908 \$20 gold coin recovered from gravels of the Fairbanks, Alaska placer district in 1959 display crystals up to $1 \mathrm{~mm}$ of secondary gold firmly attached to the surface of the coin [41]. Such activity would be expected on the gold of the SS Central America shipwreck, and would have a profound effect on gold coin preservation that would be visible even to the naked eye. However, this did not occur. The degree of preservation of these coins is ascribed to two main factors. First, compartmentalization of the gold within the shipwreck inhibited migration of bacteria that would have degraded the coins. Second, the enormous quantities of iron on the ship quickly yielded a geochemical coating that armored these coins from future attack as a passivation layer when the shipwreck degraded and gold-metabolizing bacteria moved from their placer gold host to other parts of the site. This not only prevents corrosion of the coins, but also prevents gold from being dispersed by ocean currents.

\section{Conclusions}

Black crusts that formed on gold coins recovered from the 1857 shipwreck of the SS Central America played a key role in preservation of gold artifacts from this important archeological site. While it is expected that there would be degradation of the quality of the coins in this horde, they preserve a near mint-like to proof-like state. The significant quantities of iron and steel on the shipwreck produced a fine-grained iron mineral coating on the coins within a few years of the sinking. This coating armored the coins from future chemical or biological attack. Once coated, the coins were colonized by at least 
two distinct populations of gold-tolerant bacteria that precipitated abundant nanoparticulate gold in the black crust material and produced biomineralized bacteria in a web-like mat. This demonstrates that bacteria that are known to mobilize and re-precipitate gold were probably present in the shipwreck, likely being introduced from the unrefined placer gold in the cargo. Above this middle layer of black crust, the outer layer consists of a geochemical reaction front of iron minerals, formed by the interaction of seawater with the chemical wastes of the underlying bacterial mat.

Understanding this process has application for assessing the diverse and extreme conditions under which nanoparticulate gold may form through biological processes. For example, while it is well known that iron metabolizing bacteria can thrive under high pressure and cold temperatures at deep sea shipwreck sites, this present study documents that the same is true for at least some members of the group of gold-tolerant bacteria, expanding their known environmental window of habitability.

Similarly, this study helps with our understanding of the conditions that contribute to preservation or degradation of marine archaeological materials. It can help with predictive models of the degree of precious metal preservation at sites awaiting excavation, and potentially identify sites where the precious metal artifacts may be threatened and require priority excavation.

Author Contributions: Conceptualization, methodology, and analyses were performed by all authors; sample collection and preparation, R.E.; draft preparation, E.M.; writing-review and editing was performed by all authors.

Funding: This research received no external funding. Instrumentation was funded by the W.M. Keck Foundation, and an internal grant from CSUSB.

Acknowledgments: We thank California Gold Marketing Group and Professional Coin Grading Service (PCGS) for providing access to the materials that were used in this study, and additional materials that provided context for the conditions of the shipwreck site. We also thank the hard-working members of the 2014 expedition that recovered the materials used in the study. Instrumentation used in this study was provided by a generous grant from the W.M. Keck Foundation, and an internal VETI Grant by CSUSB.

Conflicts of Interest: The authors declare no conflict of interest. The funders had no role in the design of the study; in the collection, analyses, or interpretation of data; in the writing of the manuscript, or in the decision to publish the results.

\section{References}

1. Bancroft, H.H. The Works of Hubert Howe Bancroft Volume XXII the History of California; University of California Press: Berkeley, CA, USA, 1886; Volume 1846-1848, p. 824.

2. Lindsay, B.C. Murder State: California's Native American Genocide, 1846-1873; University of Nebraska Press: Lincoln, NE, USA, 2012; p. 456.

3. Madley, B. An American Genocide: The United States and the California Indian Catastrophe, 1846-1873; Yale University Press: New Haven, CT, USA, 2016; p. 712.

4. Kinder, G. Ship of Gold in the Deep Blue Sea; Atlantic Monthly Press: New York, NY, USA, 1998; p. 560.

5. Robinson, J.W. Mines of the San Gabriels; La Siesta Press: Glendale, CA, USA, 1973; p. 72.

6. Hamann, W.E. Geology and geochemistry of the Big Horn Gold Mine, San Gabriel Mountains, Southern California. Ph.D. Thesis, University of California, Los Angeles, CA, USA, 1985.

7. Herdendorf, C.E.; Thompson, T.G.; Evans, R.D. Science on a deep-ocean shipwreck. Ohio J. Sci. 1995, 95, 4-212.

8. Landsea, C.W. The Atlantic Hurricane Database Re-Analysis Project: Documentation for the 1851-1910 Alterations and Additions to the HURDAT Database of Hurricanes and Typhoons: Past, Present and Future; Columbia University Press: New York, NY, USA, 2004; pp. 177-221.

9. Burlingame, L. The World's Most Valuable Shipwreck Discoveries; The Weather Channel. Available online: https: //weather.com/news/news/12-amazing-sunken-treasure-discoveries-20130816 (accessed on 10 April 2018).

10. Shuster, J.; Johnston, W.C.; Magarvey, A.N.; Gordon, A.R.; Barron, K.; Banerjee, R.N.; Southam, G. Structural and chemical characterization of placer gold grains: Implications for bacterial contributions to grain formation . Geomicrobiol. J. 2015, 32, 158-169. [CrossRef]

11. Shuster, J.; Reith, F.; Cornelis, G.; Parsons, J.E.; Parsons, J.M.; Southam, G. Secondary gold structures: Relics of past biogeochemical transformations and implications for colloidal gold dispersion in subtropical environments. Chem. Geol. 2017, 450, 154-164. [CrossRef] 
12. Kamenov, G.D.; Melchiorre, E.B.; Ricker, F.N.; DeWitt, E. Insights from Pb Isotopes for Native Gold Formation During Hypogene and Supergene Processes at Rich Hill, Arizona. Econ. Geol. 2013, 108, 1577-1589. [CrossRef]

13. Melchiorre, E.B.; Kamenov, G.D.; Sheets-Harris, C.; Andronikov, A.; Leatham, W.B.; Yahn, J.; Lauretta, D.S. Climate-induced geochemical and morphological evolution of placer gold deposits at Rich Hill, Arizona, USA. Geol. Soc. Am. Bull. 2017, 129, 193-202. [CrossRef]

14. Melchiorre, E.B.; Orwin, P.M.; Reith, F.; Rea, M.A.D.; Yahn, J.; Allison, R. Biological and Geochemical Development of Placer Gold Deposits at Rich Hill, Arizona, USA. Minerals 2018, 8, 1-20. [CrossRef]

15. Traverso, P.; Canepa, E. A review of studies on corrosion of metals and alloys in deep-sea environment. Ocean Eng. 2014, 87, 10-15. [CrossRef]

16. Armstrong, J.T. Quantitative analysis of silicates and oxide minerals: Comparison of Monte-Carlo, ZAF and Phi-Rho-Z procedures. In Microbeam Analysis Society; Newbury, D.E., Ed.; San Francisco Press: San Francisco, CA, USA, 1988; pp. 239-246.

17. Donovan, J.J.; Snyder, D.A.; Rivers, M.L. An improved interference correction for trace element analysis. Microbeam Annu. 1993, 2, 23-28.

18. Yeoman, R.S. A Guide Book of United States Coins (The Official Red Book), 68th ed.; Whitman Publishing: Atlanta, GA, USA, 2014; p. 464.

19. Ghiorse, W.C. Biology of iron-and manganese-depositing bacteria. Annu. Rev. Microbiol. 1984, 38, 515-550. [CrossRef]

20. Kaiho, K. Benthic foraminiferal dissolved-oxygen index and dissolved-oxygen levels in the modern ocean. Geology 1994, 22, 719-722. [CrossRef]

21. Beech Iwona, B.; Gaylarde Christine, C. Recent advances in the study of biocorrosion: An overview. Rev. Microbiol. 1999, 30, 117-190. [CrossRef]

22. Hess, D.J.; Henry-Stanley, M.J.; Barnes, A.M.; Dunny, G.M.; Wells, C.L. Ultrastructure of a novel bacterial form located in Staphylococcus aureus In Vitro and In Vivo catheter-associated biofilms. J. Histochem. Cytochem. 2012, 60, 770-776. [CrossRef] [PubMed]

23. Reith, F.; Brugger, J.; Zammit, C.M.; Nies, D.H.; Southam, G. Geobiological cycling of gold: From fundamental process understanding to exploration solutions. Minerals 2013, 3, 367-394. [CrossRef]

24. Khelissa, S.O.; Abdallah, M.; Jama, C.; Faille, C.; Chihib, N.E. Bacterial contamination and biofilm formation on abiotic surfaces and strategies to overcome their persistence. J. Mater. Environ. Sci. 2017, 8, 3326-3346.

25. Westall, F. The nature of fossil bacteria: A guide to the search for extraterrestrial life. J. Geophys. Res. Planets 1999, 104, 16437-16451. [CrossRef]

26. Forty, A.J. Corrosion micromorphology of noble metal alloys and depletion gilding. Nature 1979, $282,597$. [CrossRef]

27. Reith, F.; Etschmann, B.; Grosse, C.; Moors, H.; Benotmane, M.A.; Monsieurs, P.; Grass, G.; Doonan, C.; Vogt, S.; Lai, B.; et al. Mechanisms of gold biomineralization in the bacterium Cupriavidus metallidurans. Proc. Nat. Acad. Sci. USA 2009, 106, 17757-17762. [CrossRef]

28. Fairbrother, L.; Etschmann, B.; Brugger, J.; Shapter, J.; Southam, G.; Reith, F. Biomineralization of gold in biofilms of Cupriavidus metallidurans. Environ. Sci. Tech. 2013, 47, 2628-2635. [CrossRef]

29. Reith, F.; Lengke, M.F.; Falconer, D.; Craw, D.; Southam, G. Winogradski Review: The geomicrobiology of gold. Int. Soc. Microb. Ecol. J. 2007, 1, 567-584.

30. Reith, F.; Fairbrother, L.; Nolze, G.; Wilhelmi, O.; Clode, P.L.; Gregg, A.; Parsons, J.E.; Wakelin, S.A.; Pring, A.; Hough, R.; et al. Nanoparticle factories: Biofilms hold key to gold dispersion and nugget formation. Geology 2010, 38, 843-846. [CrossRef]

31. Wiesemann, N.; Mohr, J.; Grosse, C.; Herzberg, M.; Hause, G.; Reith, F.; Nies, D.H. Influence of copper resistance determinants on gold transformation by Cupriavidus metallidurans strain CH34. J. Bacteriol. 2013, 195, 2298-2308. [CrossRef] [PubMed]

32. Fontana, M.G.; Stactile, W. Corrosion Science and Technology; Plenum Press: London, UK, 1970; p. 268.

33. Cullimore, D.R.; Johnston, L. The impact of bioconcretious structures (rusticles) on the RMS Titanic: Implications to maritime steel structures. In Proceedings of the 2000 Annual Meeting of the Society of Naval Architects and Marine Engineers, Vancouver, BC, Canada, 6 May 2000; Volume 9, pp. 1-16.

34. Cullimore, D.R.; Johnston, L. Rusticles on the RMS Titanic. JMBA Glob. Mar. Environ. 2007, 4, 10-12. 
35. Church, R.A.; Warren, D.J.; Irion, J.B. Analysis of deepwater shipwrecks in the Gulf of Mexico: Artificial reef effect of six World War II shipwrecks. Oceanography 2009, 22, 50-63. [CrossRef]

36. Høibråten, S.; Thoresen, P.E.; Haugan, A. The sunken nuclear submarine Komsomolets and its effects on the environment. Sci. Total Environ. 1997, 202, 67-78. [CrossRef]

37. Morcillo, M.; Espada, L.; De la Fuente, D.; Chico, B. Metallic corrosion of the tanker "Prestige" in deep seawater. Rev. Metal 2004, 40, 122-126. [CrossRef]

38. Paul, S. Estimation of corrosion rate of mild steel in sea water and application of genetic algorithms to find minimum corrosion rate. Can. Metall. Q. 2010, 49, 99-106. [CrossRef]

39. Ballard, R.D. The Discovery of the Titanic; Warner Books: New York, NY, USA, 1987; p. 288.

40. Sánchez-Porro, C.; Kaur, B.; Mann, H.; Ventosa, A. Halomonas titanicae sp. nov. a halophilic bacterium isolated from the RMS Titanic. Int. J. Syst. Evol. Microbiol. 2010, 60, 2768-2774. [CrossRef] [PubMed]

41. Albanese, M.D. The Parker Gold Piece. Gold Bull. 1986, 19, 90-91. [CrossRef]

(C) 2019 by the authors. Licensee MDPI, Basel, Switzerland. This article is an open access article distributed under the terms and conditions of the Creative Commons Attribution (CC BY) license (http://creativecommons.org/licenses/by/4.0/). 